\title{
INFLUENCES OF VERAPAMIL, X-537A, A-23187 AND ADENOSINE 3',5'CYCLIC MONOPHOSPHATE ON RELEASE OF 5-HYDROXYTRYPTAMINE FROM RAT BRAIN SLICES
}

\author{
Hiroko MURAKAMI, Eiko KAJI and Tomio SEGAWA \\ Department of Pharmacology, Institute of Pharmaceutical Sciences, \\ Hiroshima University, School of Medicine, Hiroshima 734, Japan
}

Accepted February 8, 1978

\begin{abstract}
Influences of verapamil, X-537A, A-23187 and cyclic-AMP on the release of [3 H]-5-HT taken up into rat brain slices, were examined. Incubation with $40 \mathrm{mM}$ $\mathrm{KCl}$ induced tritium release which was dependent on the presence of $\mathrm{Ca}^{2+}$. Verapamil, which blocks $\mathrm{Ca}^{2}$ influx in excitable tissues, decreased potassium-induced release of 5-HT. Tritium release induced by ionophore X-537A was not dependent on extracellular (a' while that induced by $\mathrm{A}-23187$ required $\mathrm{Ca}^{2}$. Cyclic-AMP, dibutyryl cyclic-AMP and theoplylline did not significantly stimulate 5-HT release either in the presence or absence of $\mathrm{Ca}^{2+}$.
\end{abstract}

In a previous study from this laboratory we showed that high-potassium induced $\left[{ }^{3} \mathrm{H}\right]-5$-hydroxytryptamine $\left(\left[{ }^{3} \mathrm{H}\right]-5-\mathrm{HT}\right)$ release from rat brain synaptosomes was not affected when the amount of $\mathrm{Ca}^{21}$ in the medium was decreased by $50 \%$ of the normal but such was completely abolished in $\mathrm{Ca}^{2+}$-free medium in the presence of EGTA (1). Our explanation is that although potassium-induced release of 5-HT is entirely dependent on $\mathrm{Ca}^{2+}$, only a small amount of $\mathrm{Ca}^{2+}$ in the medium is required to be transported into nerve terminals and intra- or extracellularly bound endogenous $\mathrm{Ca}^{2+}$ can be utilized for potassium-induced release of 5-HT.

Verapamil or its methyl-derivative D-600 is a drug that blocks $\mathrm{Ca}^{2+}$ influx in excitable tissue (2-4). X-537A and A-23187, which are termed ionophores, have been reported to bind $\mathrm{Ca}^{2+}$ and transport it across lipid membrane (5-7). It was therefore considered that these agents may be useful tools to obtain further information on the role of $\mathrm{Ca}^{2+}$. In addition, the effect of adenosine $3^{\prime}, 5^{\prime}$-cyclic monophosphate (cyclic-AMP) on high potassiuminduced release of 5-HT was studied, since there is evidence suggesting that this nucleotide can increase $\mathrm{Ca}^{2+}$ permeability $(8,9)$ and facilitate the release of transmitters.

\section{MATERIALS AND METHODS}

The following drugs were generously donated: Verapamil (Eisei Pharmaceutical Co., Ltd., Tokyo, Japan); X-537A (Nippon Roche Research Center, Kamakura, Japan); A-23187 (Lilly Research Lab., Indianapolis, Ind.). 5-Hydroxy[G-3 ${ }^{3}$ ]tryptamine creatinine sulphate $\left(\left[{ }^{3} \mathrm{H}\right]-5-\mathrm{HT}\right)(500 \mathrm{mCi} / \mathrm{mmole})$ was obtained from the Radiochemical Centre, Amersham. Adenosine 3',5'-cyclic monophosphate and dibutytryl adenosine 3',5'-cyclic monophosphate (dibutyryl cyclic-AMP) were purchased from Kyowa Hakko Kogyo Co., Ltd. (Tokyo, 
Japan); Theophylline was from Katayama Chemical Industry Ltd. (Osaka, Japan).

Uptake of $\left[{ }^{3} \mathrm{H}\right]-5-H T$

Malc Wistar rats weighing from 100 to $140 \mathrm{~g}$ were decapitated and the whole brain was rapidly removed and placed on wet (Krebs-Ringer bicarbonate solution) filter paper on ice. A coronal section of the brain was made about $4 \mathrm{~mm}$ from the anterior pole of the cerebral hemispheres and slices (diameter $3 \mathrm{~mm}$, thick 0.4 to $0.5 \mathrm{~mm}$, wet weight approx. $20 \mathrm{mg}$ ) of cerebral cortex and neostriatum were prepared from the posterior portion with a razor blade. These slices were suspended in $\mathrm{O}_{2}$-saturated Krebs-Ringer bicarbonate solution containing $2 \times 10^{-7} \mathrm{M}$ pheniprazine (a monoamine oxidase inhibitor), $0.02 \%$ ascorbic acid and $\left[{ }^{3} \mathrm{H}\right]-5-\mathrm{HT}$ (final concentration of $10^{-} \mathrm{M}$ ) and were incubated at $37^{\circ} \mathrm{C}$ for $30 \mathrm{~min}$.

\section{Release of $\left[{ }^{3} H\right]-5-H T$}

After rinsing scveral times in fresh medium, the slices were suspended in $0.5 \mathrm{ml}$ of the medium and again incubated at $37^{\circ} \mathrm{C}$. The medium was renewed every $5 \mathrm{~min}$ for $30 \mathrm{~min}$, thereafter they were incubated in the medium containing $40 \mathrm{mM} \mathrm{KCl}(40 \mathrm{mM} \mathrm{NaCl}$ was omitted) for $5 \mathrm{~min}$. Unless otherwise stated, the agents to be tested were dissolved in $0.015 \mathrm{M}$ Tris-buffered saline ( $\mathrm{pH}$ 7.4) and were diluted with Krebs-Ringer bicarbonate solution when tested. In each experiment, the fraction for every 5 min was collected in a scintillation vial containing $10 \mathrm{ml}$ Bray's solution and the radioactivity was determined in a model 3320 Packard Tri-Carb liquid scintillation spectrometer and corrected for efficiency by external standardization. Counting efficiency was approx. $20 \%$.

Release of $\left[{ }^{3} \mathrm{H}\right]-5-\mathrm{HT}$ was expressed as dpm. The potassium-induced $\left[{ }^{3} \mathrm{H}\right]-5-\mathrm{HT}$ release was also expressed as percent of spontaneous tritium release during $5 \mathrm{~min}$ before high potassium.

A-23187 and X-537A were dissolved in DMSO and an approximate dilution was made in Krebs-Ringer bicarbonate solution so that the concentration of DMSO did not exceed $1 \%$.

The Krebs-Ringer bicarbonate solution was composed of $118 \mathrm{mM} \mathrm{NaCl}, 4.7 \mathrm{mM} \mathrm{KCl}$, $2.5 \mathrm{mM} \mathrm{CaCl}_{2}, 1.13 \mathrm{mM} \mathrm{MgCl}_{2}, 1.2 \mathrm{mM} \mathrm{NaH} \mathrm{mPO}_{4}, 25 \mathrm{mM} \mathrm{NaHCO}$ and $11 \mathrm{mM}$ glucaose.

\section{RESULTS}

Potassium-induced release and $\mathrm{Ca}^{2+}$ dependency

As is shown in Fig. 1, incubation of brain slices in the medium containing $40 \mathrm{mM} \mathrm{KCl}$ for 5 min produced a striking increase in [ $\left.{ }^{3} \mathrm{H}\right]-5-\mathrm{HT}$ release, the efflux being increased to 4.2 times the control. In preliminary experiments, the release of tritium was examined for the presence of metabolite of $\left[{ }^{3} \mathrm{H}\right]-5-\mathrm{HT}$ and it was found that the proportion of unchanged $\left[{ }^{3} \mathrm{H}\right]-5-\mathrm{HT}$ was $63.5 \%$ of the total release of radionctivity in spontaneous release, while in the potassium-induced release such was $82.1 \%$

As is shown in Table 1, pre-incubation with $\mathrm{Ca}^{2+}$-free medium for 5 min failed to modify both the potassium-induced and spontaneous relcases. However, when the slices were incubated with $\mathrm{Ca}^{2+}$ free medium for 30 min or with $\mathrm{Ca}^{2+}$-free mediun in the presence of EGTA (2.5 mM) for $5 \mathrm{~min}$, the potassium-induced relcase was significantly attenuated 


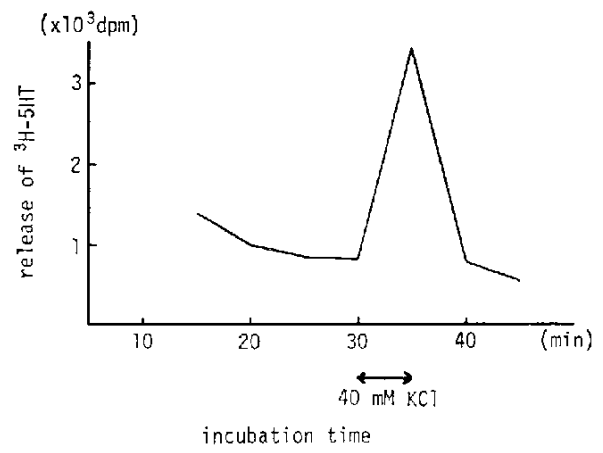

FiG. 1. Release of [ $\left.{ }^{3} \mathrm{H}\right]-5-\mathrm{HT}$ from rat brain slices. Rat brain slices, pre-loaded with $\left[{ }^{3} \mathrm{H}\right]-5-\mathrm{HT}$ were incubated at $37^{\circ} \mathrm{C}$. Release is expressed as dpm during $5 \mathrm{~min}$ incubation.

TABLE 1. Efrect of $\mathrm{Ca}^{2+}$-deficiency on $\left.{ }^{3} \mathrm{H}\right]-5-\mathrm{HT}$ release from rat brain slices

\begin{tabular}{lcccc}
\hline Medium & $\begin{array}{c}\text { Condition } \\
\text { Incubation time } \\
(\mathrm{min})\end{array}$ & $\begin{array}{c}\text { Spontaneous } \\
(\mathrm{dpm})\end{array}$ & $\begin{array}{c}\text { Release } \\
\text { Potassium-induced } \\
(\mathrm{dpm})\end{array}$ & $\begin{array}{c}\text { Potassium-induced } \\
\begin{array}{c}\text { Spontaneous } \\
(\%)\end{array}\end{array}$ \\
Normal & 5 & $639.92(7)$ & $2640 \pm 334(7)$ & $420.3 \pm 17.0(7)$ \\
$\mathrm{Ca}^{2+}$-free & 5 & $583 \pm 77(3)$ & $2548 \pm 542(3)$ & $429.0 \pm 22.4(3)$ \\
$\mathrm{Ca}^{2+}$-free & 20 & $542 \pm 72(4)$ & $1062 \pm 248(4)^{*}$ & $191.3 \pm 20.7(4)^{*}$ \\
$\mathrm{Ca}^{2+}$-free & 5 & $872 \pm 242(4)$ & $1098 \pm 256(4)^{*}$ & $129.6 \pm 5.1(4)^{*}$ \\
EGTA $(2.5 \mathrm{mM})$ & & & & \\
\hline
\end{tabular}

Rat brain slices, pre-loaded with $\left[{ }^{3} \mathrm{H}\right]-5-\mathrm{HT}$ were incubated at $37^{\circ} \mathrm{C}$. Spontaneous release is dpm during 5 min incubation before addition of high polassium. Potassiuminduced release is dpm during 5 min incubation with $40 \mathrm{mM} \mathrm{KCl}$. Values are mean \pm S.E.M. of number of determinations indicated in parentheses. ${ }^{*} \mathrm{P}<0.01$.

TABle 2. Effoct of verapamil on $\left[{ }^{3} \mathrm{H}\right]-5-\mathrm{HT}$ release from rat brain slices

\begin{tabular}{|c|c|c|c|}
\hline $\begin{array}{l}\text { Concentration of } \\
\text { verapamil } \\
\text { (M) }\end{array}$ & $\begin{array}{l}\text { Spontaneous } \\
\text { (dpm) }\end{array}$ & $\begin{array}{c}\text { Release } \\
\text { Potassium-induced } \\
\text { (dpm) }\end{array}$ & $\frac{\text { Potassium-induced }}{\text { Spontaneous }}$ \\
\hline Control & $894 \pm 85$ & $2931 \pm 305$ & $345.3 \pm 3.1$ \\
\hline $10^{-6}$ & $900 \pm 96$ & $3122 \pm 389$ & $347.1 \pm 22.7$ \\
\hline $10^{-5}$ & $1037 \pm 139$ & $2463 \pm 330$ & $238.5 \pm 21.8^{*}$ \\
\hline $10^{-4}$ & $1342 \div 91^{*}$ & 1096 上 $73^{*}$ & $81.9 \pm 2.4^{*}$ \\
\hline
\end{tabular}

Rat brain slices, pre-loaded with $\left[{ }^{3} \mathrm{H}\right]-5-\mathrm{H} \mathrm{T}$ were incubated at $37^{\circ} \mathrm{C}$. Slices were incubated with verapamil for $30 \mathrm{~min}$ before addition of high potassium. Release is expressed as dpm during 5 nin incubation. Values aro mean + S.E.M. of 5 determinations. $* \mathrm{P}<0.01$.

while spontaneous release was markedly but not signilicantly increased in $\mathrm{Ca}^{2+}-$ free and EGTA-containing medium.

\section{Effect of verapamil}

The results are shown in Table 2. Verapamil was introduced into the incubation medium 
30 min before potassium stimulation. At $10^{-6} \mathrm{M}$, verapamil did not produce any significant change in either spontaneous or potassium-induced $\left[{ }^{3} \mathrm{H}\right]-5-\mathrm{HT}$ release. At $10^{-5}$ and $10^{-4} \mathrm{M}$, however, verapamil induced an increase in spontaneous release and at decrease in potassiuminduced release.

\section{Effect of $X-537 A$ and $A-23187$}

When the slices were exposed to the medium containing either X-537A or A-23187, there was marked increase in $\left[{ }^{3} \mathrm{H}\right]-5-\mathrm{HT}$ release. Fig. 2 shows the time course of the effect of these ionophores. The rate of increased release by X-537A $\left(10^{-5} \mathrm{M}\right)$ was rapid. Thus, within 5 min there was approx. $5 \times 10^{3} \mathrm{dpm}$ of tritium release, thereafter the release increased

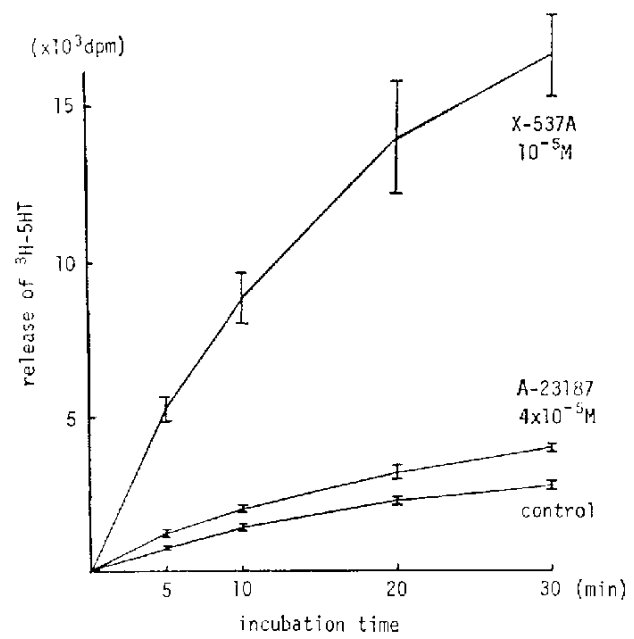

FIG. 2. Time course of X-537- and A-23187-induced [ $\left.{ }^{3} \mathrm{H}\right]-5$ - $\mathrm{HT}$ release from rat brain slices. Rat brain slices, pre-loaded with $\left[{ }^{3} \mathrm{H}\right]-5-\mathrm{HT}$ were incubated at $37^{\circ} \mathrm{C}$ with ionophores. Values are mean $\rfloor$ S.E.M. of 5 determinations.

TABLE 3. Effect of $\mathrm{Ca}^{2+}$-deficiency on X-537A- and A-23187-induced release of $\left[{ }^{3} \mathrm{H}\right]-5-\mathrm{HT}$ from rat brain slices

\begin{tabular}{|c|c|c|c|}
\hline \multirow{2}{*}{ Drugs } & \multirow{2}{*}{ (M) } & \multicolumn{2}{|c|}{ Medium } \\
\hline & & Normal & $\mathrm{Ca}^{2+}$-free \\
\hline \multicolumn{4}{|l|}{ Control } \\
\hline$(1 \%$ DMSO $)$ & & $1184+107(8)$ & 1295 J $58(8)$ \\
\hline \multirow[t]{2}{*}{$\mathrm{X}-537 \mathrm{~A}$} & $10^{-6 j}$ & $5493 \quad 448(6)$ & $6155 \div 324(6)$ \\
\hline & $10^{-5}$ & $5189 \mid 661$ & $5815: 492(5)$ \\
\hline \multirow[t]{3}{*}{ A.23187 } & $4 \times 10^{-3}$ & $591 \pm 150(5)$ & $247 \div 163(5)$ \\
\hline & $10^{-1}$ & $798 ! .124(6)$ & $327 ! 92(6)^{*}$ \\
\hline & $2 \times 10^{-4}$ & $1155: 225(6)$ & $717 ! 158(6)$ \\
\hline
\end{tabular}

Rat brain slices, pre-loaded with $\left[{ }^{3} \mathrm{H}\right]-5-1 \mathrm{TT}$ were incubated at $37^{\circ} \mathrm{C}$ for $10 \mathrm{~min}$. Ionophoreinduced release was expressed as the difference between $\mathrm{dpm}$ relcased by $1 \%$ DMSO and by ionophore. Values are mean $\perp$ S.E.M. of number of determinations indicated in parentheses.

* Significantly different at $\mathrm{P}<0.02$ from the values in normal medium. 
almost linearly for about $20 \mathrm{~min}$, after which the rate somewhat declined. A-23187 was less potent than $\mathrm{X}-537 \mathrm{~A}$ in releasing $\left[{ }^{3} \mathrm{H}\right]-5-\mathrm{HT}$ from brain slices (Fig. 2). Preliminary experiments indicated that when the slices were incubated with $40 \mathrm{mM} \mathrm{KCl}$ for more than 5 min there was no further increase in tritium release.

The influence of omission of $\mathrm{Ca}^{2+}$ from the medium on the $\left[{ }^{3} \mathrm{H}\right]-5-\mathrm{HT}$ release induced by ionophore was examined, using $10 \mathrm{~min}$ incubation with ionophore. In this experiment, ionophore-induced release was expressed as the difference between the radioactivity release by $1 \%$ DMSO and by and by ionophore in DMSO (Table 3). A-23187 $\left(4 \times 10^{-5}-2 \times 10^{-4}\right.$ $\mathrm{M}$ ) increased the tritium release in $\mathrm{Ca}^{2+}$-normal medium, depending on the concentration employed. The effect was considerably reduced when the experiment was performed under $\mathrm{Ca}^{2+}$-free condition (significantly different at $10^{-4} \mathrm{M} \mathrm{A-23187).} \mathrm{X-537A,} \mathrm{at} 10^{-6} \mathrm{M}$, remarkably increased the tritium release in normal medium but no further increase in release was observed at $10^{-5} \mathrm{M}$. The omission of $\mathrm{Ca}^{2+}$ from the medium failed to attenuate the effect of X-537A, rather such was increased.

\section{Effect of cyclic-AMP}

The results are summarized in Table 4. Cyclic-AMP $\left(10^{-\frac{1}{4}} \mathrm{M}\right)$ did not affect either spontaneous or potassium-induced $\left[{ }^{3} \mathrm{H}\right]-5-\mathrm{HT}$ release. Dibutyryl cyclic-AMP, at the same concentration, slightly but not significantly increased potassium-induced release without affecting spontancous release. Theophylline $\left(10^{-3} \mathrm{M}\right)$ had no effect on tritium release. When the slices were incubated in the medium containing cyclic-AMP $\left(10^{-4} \mathrm{M}\right)$ and theophylline $\left(10^{-3} \mathrm{M}\right)$, there was no change in cither spontancous or potassium-induced release. Cyclic-AMP $\left(10^{-4} \mathrm{M}\right)$ had no effect on tritium release in $\mathrm{Ca}^{2+}$-free medium.

TaBle 4. Effect of cyclic-AMP, dibutyryl cyclic-AMP and theophylline on $\left[{ }^{3} \mathrm{H}\right]-5-\mathrm{HT}$ relcase from rat brain slices

\begin{tabular}{|c|c|c|c|c|c|}
\hline Medium & Drugs & $\begin{array}{c}\text { Concentration } \\
\text { (M) }\end{array}$ & $\begin{array}{c}\text { Spontaneous } \\
\text { (dpm) }\end{array}$ & $\begin{array}{c}\text { Release } \\
\text { Potassium-induced } \\
(\mathrm{dpm})\end{array}$ & $\frac{\text { Potassium-induced }}{\text { Spontaneous }}$ \\
\hline \multirow[t]{8}{*}{ Normal } & Control & & 691 上 $25(6)$ & $2895 \doteq 125(6)$ & $420 \perp 16(6)$ \\
\hline & Cyclic-AMP & $10^{-4}$ & $743 \div 30(6)$ & $2906 \pm 199(6)$ & $389 \pm 14(6)$ \\
\hline & Control & & $706+109(8)$ & $2299 \pm 364(8)$ & $347-41(8)$ \\
\hline & $\begin{array}{l}\text { Dibutyryl } \\
\text { cyclic-AMP }\end{array}$ & $10^{-4}$ & 719 土 $119(8)$ & $2625 \pm 357(8)$ & $384 \pm 23(8)$ \\
\hline & Control & & $694 \perp 33(6)$ & $2661 \pm 87(6)$ & $387 \pm 27(6)$ \\
\hline & Theophylline & $10^{-3}$ & $694+75(6)$ & $2586 \pm 96(6)$ & $389+33(6)$ \\
\hline & Control & & 640 上 $60(6)$ & $2056+297(6)$ & $346 \perp 55(6)$ \\
\hline & $\begin{array}{c}\text { Cyclic-AMP } \\
\therefore \\
\text { Theophylline }\end{array}$ & $\begin{array}{l}10^{-4} \\
10^{:}\end{array}$ & 565 土 $54(6)$ & $1832=140(6)$ & $343 \pm 46(6)$ \\
\hline \multirow[t]{4}{*}{$C a^{21}-$ free } & Control & & $564: 53(6)$ & $853 \div 40(6)$ & $156 \div 10(6)$ \\
\hline & Cyclic-AMP & $10^{-4}$ & 576 . $45(6)$ & $847 \perp 25(6)$ & 150 上 $8(6)$ \\
\hline & Control & & $1115 \pm 194(6)$ & $1946 \pm 325(6)$ & $179+15(6)$ \\
\hline & Dibutyryl & $10^{-4}$ & $964+134(8)$ & $1742+256(8)$ & 179 上 $7(8)$ \\
\hline
\end{tabular}

Rat brain slices, pre-loaded with $\left[{ }^{3} \mathrm{H}\right]-5-\mathrm{HT}$ were incubated with drugs at $37^{\circ} \mathrm{C}$ for $5 \mathrm{~min}$. Values are mean $t$ S.E.M. of number of determinations indicated in parentheses. 


\section{DISCUSSION}

As in the case of other putative transmitters, depolarization by high potassium cffectively released $\left[{ }^{3} \mathrm{H}\right]-5-\mathrm{HT}$ from brain slices. Furthermore, potassium-induced release appeared to be dependent on the presence of $\mathrm{Ca}^{2+}$. However, 5-HT release could be abolished only when the preparation was incubated with $\mathrm{Ca}^{2+}$-free medium for 30 min or with $\mathrm{Ca}^{2+}$-free medium in the presence of EGTA for $5 \mathrm{~min}$. These results are generally coincident with our previous observations with synaptosomes (1).

D-600, an analogue of verapamil, was found to inhibit both vasopressin and oxytocin release from the neurohypophysis $(4,10)$, and catecholamine from the adrenal medulla (11). Our result shows that verapamil, at a concentration which is known to be effective in blocking $\mathrm{Ca}^{2+}$ entry, decreased potassium-induced 5-HT release. Therefore, influx of $\mathrm{Ca}^{2+}$ into the nerve cell is a necessary event for release of $\left[{ }^{3} \mathrm{H}\right]-5-\mathrm{HT}$.

The antibiotics ionophores X-537A and A-23187 are known to form at lipophilic complex with monovalent and/or divalent cations, thereby increasing their permeability of biological membrane. Ionophores have also been shown to induce catccholamine release from peripheral adrenergic neurons (12), brain synaptosomes $(13,14)$ and adrenal medulla (15) ACh release from brain slices (16) and ATP from platelets (17). The results presented here on release of $\left[{ }^{3} \mathrm{H}\right]-5-\mathrm{HT}$ from brain slices are consistent with these observations. X-537A released approximately 4 times as much tritium as did $A-23187$, though the concentration was only one fourth that of A-23187. The release of [ $\left.{ }^{3} \mathrm{H}\right]-5-\mathrm{HT}$ from slices by A-23187 was markedly reduced when $\mathrm{Ca}^{2+}$ was omitted. These results are similar to those observed in the case of catecholamine release $(12,13)$. On the other hand, X-537A action did not require $\mathrm{Ca}^{2+}$ in the medium. X-537A differs from $\mathrm{A}-23187$ in that it has relatively little selectivity for divalent cations (18). It forms lipophilic complexes with monovalent cations such as $\mathrm{Na}^{+}, \mathrm{K}^{+}, \mathrm{Cs}^{+}$and $\mathrm{H}^{+}$. Howcver, the possibility that $\mathrm{X}-537 \mathrm{~A}$ depolarized the preparation by increasing $\mathrm{Na}^{+}$entry is excluded, since the effect did not require extracellular $\mathrm{Ca}^{2+}$. Though the possibility that X-537A may act as Ca-ionophore in the presence of a trace amount of external $\mathrm{Ca}^{2+}$ cannot be excluded, there is also the possibility that $\mathrm{X}-537 \mathrm{~A}$ enters the cell thus causing $\mathrm{Ca}^{2+}$ to be released from intracellular stores (19) or X-537A releases 5-HT by an indirect, reserpine like mechanism (12).

Theophylline, cyclic-AMP and dibutyryl cyclic-AMP can stimulate catecholamine release from the adrenal medulla in the absence of external $\mathrm{Ca}^{2}+(20)$. Similarly, independently of external $\mathrm{Ca}^{2+}$, phosphodiesterase inhibitors, aminophylline or caffeine can stimulate catecholamine release from the adrenal medulla $(21,22)$ and dibutyryl cyclic-AMP and theophylline can release norepinephrine from sympathetic nerves (23). On the basis of these observations, it has been suggested that cyclic- $A M P$ may stimulate relcase by mobilizing intracellular, bound $\mathrm{Ca}^{2-t}$. In the present experiment, it was shown that cyclic-AMP, dibutyryl cyclic-AMl' and theophylline did not significantly stimulate [ ['H]-5-HT release either in the presence or absence of external $\mathrm{Ca}^{2+}$. It would thus appear that in serotonergic nerve terminals, cyclic-AMP is not involved in mobilizing intracellular, bound $\mathrm{Ca}^{2+}$.

Acknowledgement: This work was supported in part by grant No. 137014 for the 
research of science from the Department of Education, Science and Culture, Japan.

\section{REFERENCES}

1) Slgawa, T., Murakavi, H!, Inolyl, A. and Tanaka, Y.: Influences of colchicine, vinblastine and cytochalasin on the release of 5-hydroxytryptamine from rat brain synaptosomes. J. Neurochem. 30, 175-180(1978)

2) Fi.fickenstein, A., Grün, G., Trit7hart, H. And Byon, K.: Uterus-relaxation durch hochactive $\mathrm{Ca}^{++}$-antagonistische Hemmstoffe der electro-mechanischen Koppelung wic Isoptin (Verapamil, Iproveratril), Substanz D 600 und Segontin (Prenylamin). Klin. Wshcr. 49, 32-41 (1971)

3) Baker, P.F., Meves, H. AND Ridoway, E.B.: Calcium entry in response to maintained depolarization of squid axons. J. Physiol. 231, 527-548 (1973)

4) Dreifuss, J.J., Grau, J.D. and Nordmann, J.J.: Eflects on the isolaled neurohypophysis of agents which affect the membrane permeability to calcium. J. Physiol. 231, 96P-98P (1973)

5) Caswell, A.H. a.vd Prlssman, B.C.: Kinetics of transport of divalent cations across sarcoplasmic reticulum vesicles infuced by ionophores. Biochem. biophys. Res. Commun. 49, 292-298 (1972)

6) Reed, P.W. AND Lardy, H.A.: A23187: A divalent calion ionophore. J. biol. Chem. 247, 6970-6977 (1972)

7) SCARPA, A. AND INESI, G.: Ionophore mediated equilibration of calcium ion gradients in fragmented sarcoplasmic reticulum. FEBS Letters 22, 273-277 (1972)

8) Miyamoto, M.D. ANd Breckenridge, B. MCL.: A cyclic adenosine monophosphate link in the catecholamine enhancement of transmitter release at the neuromuscular junction. J. gen. Physiol. 63, 609-624 (1974)

9) Parpano, A.J.: Calcium-dependent action potentials produced by catecholamines in guinea pig atrial muscle fibers depolarized by potassium. Circulation Res. 27, 379-390 (1970)

10) Russfi, J.T. AND TIIORN, N.A.: Calcium and stimulus-secretion coupling in the neurohypophysis. 11. Lffects of lanthanum, a verapamil analogue (D-600) and prenylamine on 45-calcium transport and vasopressin release in isolated rat neurohypophysis. Acta chdocr., Khh 76, 471-487 (1974)

1I) Pinto, J.E.B. and Trifaro, J.M.: The different effects of D-600) (methoxyverapamil) on the release of adrenal catecholamines induced by acetyleholine, high potassium or sodium deprivation. Brit. J. Pharmacol. 57, 127-132 (1976)

12) ThoA, N.B., Costa, J.L., Moss, J. And Koris, I.J.: Mechanism of release of norepinephrine from peripheral adrenergic neurons by the calcium ionophores X537A and A23187. Life Sci. 14, 1705-1719 (1974)

13) Colburn, R.W., ThOA, N.B. AND Kopin, I.J.: Influences of ionophores which bind calcium on the release of norepinephrine from synaptosomes. Life Sci. 17, 1395-1400 (1975)

14) HoLtz, R.W.: The release of dopamine from syllaptosomes from rat striatum by the ionophores X537^ and A23187. Biochim. Biophys. Actu 375, 138-152 (1975)

15) Cochrane, D.E., Dougitas, W.W., Moliri, T. and Nakazato, T.: Calcium and stimulussecretion coupling in the adrenal medulta: Contrasting stimulating effects of the ionophores X-537A and A23187 on catecholamine output. J. Physiol, 252, 363-378 (1975)

16) Richter, J.A.: The ionophores X537A (Lasolocid) transiently increases acetylcholine release from rat brain in vitro. Life Sci. 20, 701-714 (1977)

17) Fetingan, R.D. and Detwit.r. T.C.: Platelet secretion induced by divalent cation ionophores. Nature 249, 172-173 (1974)

18) Pressman, B.C.: Properties of ionophores with broad range cation selectivity. Fedn Proc. 32, $1698-1703(1973)$

19) Ricci, A. Jr., SAndrrs, K.M., Portmorl, J. and yan der Kloot, W.G.: Effects of the ionophore, X-537A and A-23187 on catecholamine release from the in vitro frog adrenal. Life Sci. 16, 177 184 (1974)

20) PeAch, M.J.: Stimulation of release of adrenal catecholamine by adenosine $3^{\prime}, 5^{\prime}$-cyclic mono- 
phosphate and theophylline in the absence of extracellular $\mathrm{Ca}^{++}$. Proc. natn. Acad. Sci. U.S.A. 69, 834-836 (1972)

21) PoISNer, A.M.: Direct stimulant effect of aminophylline on catecholamine release from the adrenal medulla. Biochem. Pharmacol. 22, 469-476 (1973)

22) PoIsner, A.M.: Caffeine-induced catecholamine secretion: Similarity to caffeine-induced muscle contraction. Proc. Soc. exp. Biol. Med. 142, $103-105$ (1973)

23) Wooth, G.F., ThoA, N.B., Kopin, I.J. AND Axflrod, J.: Enhanced release of dopaminc $\beta$-hydroxylase and norepinephrine from sympathetic nervous by dibutyryl cyclic adenosine 3',5'monophosphate and theophylline. Mol. Pharmacol. 9, 178-183 (1972) 